\title{
Bacille Calmette-Guérin vaccination and tuberculosis
}

I

I suppose that I was attracted to respiratory diseases by tuberculosis (TB) as much as anything else. As a second year medical student in the mid1950s, I elected to write a paper about TB therapy (everyone in the class had to write a paper on something) and there seemed to be a lot of new information out there about the treatment of this subtle disease. In the process, I interviewed the local expert and was invited to rounds at the regional sanitorium, where cases ( $\mathrm{x}$-rays) were presented and decisions made about what to do next. It was, of course, fascinating. The treatment consisted of streptomycin, para-amino-salicylic acid

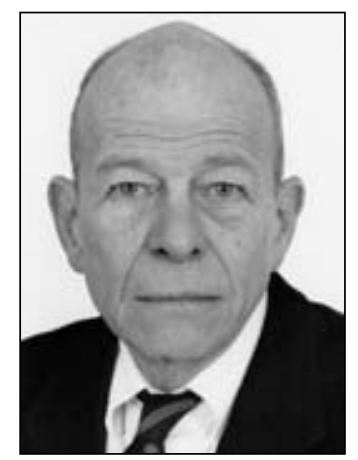

Nick R Anthonisen

\section{Le vaccin contre le bacille de Calmette-Guérin et la tuberculose}

and isoniazid (new at the time), followed by surgical resection of the remaining cavitary disease, which was thought incurable by medical means. The surgery carried major risks, and its timing was felt to be critical to eventual cure. For years after, I remained interested in $\mathrm{TB}$, doing part of my postgraduate training at a North Carolina sanitorium. One of the controversies in the field at the time was the value, or lack of it, of bacille Calmette-Guérin (BCG) vaccination. Forty years later, the paper in this issue of the Canadian Respiratory Journal by Cook et al (pages 134-138) indicates that although a lot more is known and new evaluative procedures have been developed, this issue is not dead.

Cook et al used molecular typing of positive TB cultures to identify 'clusters' of cases infected with the same tubercle bacilli, and on the assumption that clusters represented evidence for person-to-person transmission of the pathogen, asked whether BCG vaccination reduced the frequency of such clusters. Their subjects were western Canadian Aboriginals, a population with a substantial incidence of TB. Their study has several strengths other than its sophisticated molecular technology. It included most of the Aboriginals living west of Thunder Bay, Ontario, used a common laboratory for the analysis of the organisms and the same vaccine, and was able to document the BCG status of $84 \%$ of the individuals with positive TB cultures. These strengths are attributable to the highly organized way that TB is dealt with (at least in western Canada), and to the fact that TB is, by law, a reportable disease. The result is an excellent database.

Approximately one-third of the TB cases had had BCG vaccination; they tended to be younger than those who had not been vaccinated. Clustering occurred in about $60 \%$ of cases and did not differ according to BCG status, either in crude analysis or multivariate analyses that adjusted for potential confounders, including age. BCG status did not relate to cluster size. The authors interpreted clusters of the same organism infecting numbers of peoples over a restricted time interval as evidence of person-to-person transmission and, therefore, concluded that BCG vaccination does not prevent such transmission. They questioned the efficacy of BCG vaccination, at least streptomycine, d'acide para-aminosalicylique et d'isoniazide (nouveau à l'époque), suivi d'une résection chirurgicale de la maladie cavitaire, qu'on pensait médicalement incurable. L'intervention chirurgicale comportait des risques considérables, et on pensait le moment de l'exécuter capital pour une guérison éventuelle. Pendant des années, j’ai continué à m'intéresser à la TB, et j'ai fait une partie de ma formation postdoctorale dans un sanatorium de Caroline du Nord. L'une des controverses dans le domaine à l'époque était la valeur, ou l'absence de valeur, du vaccin contre le bacille de Calmette-Guérin (BCG). Quarante ans plus tard, l'article de Cook et coll., (page 134-138) publié dans le présent numéro du Canadian Respiratory Journal, indique que même si on en sait beaucoup plus et si de nouvelles interventions évaluatives sont au point, la question demeure.

Cook et coll. utilisent le typage moléculaire des cultures de TB positives pour repérer des « concentrations » de cas infectés par le même bacille de TB et, d'après l'hypothèse que ces concentrations de cas représentent des preuves de transmission interhumaine du pathogène, ils se sont demandé si le vaccin contre le BCG en réduit la fréquence. Leurs sujets témoins étaient des autochtones de l'Ouest canadien, une population présentant une incidence élevée de TB. L'étude comportait plusieurs points forts, en plus d'une technologie moléculaire de pointe. Elle incluait la plupart des autochtones habitant à l'ouest de Thunder Bay, en Ontario, faisait appel à un laboratoire courant pour analyser les organismes et le même vaccin, et permettait de documenter l'état du BCG chez $84 \%$ des individus présentant des cultures de TB positives. Ces forces sont attribuables à la manière hautement organisée dont on affronte la TB (du moins dans l'Ouest canadien) et au fait qu'il s'agit d'une maladie à déclaration obligatoire. Il en découle une excellente base de données.

Environ le tiers des cas de TB avaient été vaccinés contre le BCG. Ils tendaient à être plus jeunes que les cas non vaccinés. Des concentrations se manifestaient dans environ $60 \%$ des cas et ne différaient pas en matière de statut du BCG, que ce soit par l'analyse brute ou par l'analyse multivariée rajustant les variables confusionnelles potentielles, y compris l'âge. Le statut du BCG n'était pas relié à l'importance des concentrations. Les 
in adults, because if it prevented disease activity, it should have also reduced infectivity and clustering, and it did not.

It is hard to argue with the conclusions of Cook et al. While clustering may represent an endemic strain as well as spread, it must reflect spread to some extent. One could argue that this was not a randomized trial; BCG vaccination was given to onethird of the cases, apparently by choice of the relevant health care worker and/or the parents of the children involved. Obviously, this choice could have biased the sample in some way. If, for example, BCG vaccination were employed in communities that had very high rates of transmission, then equivalent degrees of clustering between vaccinated and nonvaccinated individuals might represent a positive vaccine effect. This seems unlikely because the overall rate of clustering $(50 \%$ to $60 \%)$ was similar to that observed in Aboriginal communities at large.

So, if $\mathrm{BCG}$ vaccination did not reduce $\mathrm{TB}$ transmission indicated by clustering, is BCG vaccination effective? And, should people be vaccinated? There is ample evidence from clinical trials (1-3) that BCG vaccination does reduce active $\mathrm{TB}$, so why did it not work in the setting examined by Cook et al? I think the explanation is that the BCG vaccine has a protective effect, but the duration of the effect is limited to something on the order of 10 years (3). Presumably, most of the patients studied by Cook et al had outgrown their immunity. The limited duration of the protection afforded by BCG vaccination is of value, however, because it is particularly effective at preventing disseminated TB (including meningitis [2,3]), which causes devastating illnesses in children. It is, therefore, still reasonable to offer the BCG vaccine to Aboriginal children, and it will continue to be reasonable until the burden of $\mathrm{TB}$ in this community is reduced to the level in nonAboriginal, native-born Canadians. As Cook et al emphasized, there is a long way to go to achieve this.

Nick R Anthonisen MD Editor-in-Chief, Canadian Respiratory Journal

\section{REFERENCES}

1. Clemens JD, Chuong JJ, Feinstein AR. The BCG controversy. A methodological and statistical reappraisal. JAMA 1983;249:2362-9.

2. Colditz GA, Brewer TF, Berkey CS, et al. Efficacy of BCG vaccine in the prevention of tuberculosis. Meta-analysis of the published literature. JAMA 1994;271:698-702.

3. Colditz GA, Berkey CS, Mosteller F, et al. The efficacy of bacillus Calmette-Guerin vaccination of newborns and infants in the prevention of tuberculosis: Meta-analyses of the published literature. Pediatrics 1995;96:29-35. auteurs ont interprété des concentrations du même organisme infectant un certain nombre de personnes pendant un intervalle de temps restreint comme un élément probant de transmission interhumaine et, par conséquent, ont conclu que le vaccin contre le BCG ne prévient pas cette transmission. Ils ont remis en question le vaccin contre le BCG, du moins chez les adultes, parce que s'il prévenait l'activité de la maladie, il aurait dû réduire l'infectiosité et la formation de concentrations, ce qu'il n'a pas fait.

Il est difficile de contredire les conclusions de Cook et coll. Tandis que les concentrations peuvent représenter une souche endémique tout autant qu'une propagation, elles doivent refléter les propagations dans une certaine mesure. On pourrait prétendre qu'il ne s'agissait pas d'un essai aléatoire, puisque le vaccin contre le BCG a été administré au tiers des cas, apparemment au choix du dispensateur de soins ou des parents des enfants en cause. De toute évidence, ce choix a pu fausser l'échantillon. Si, par exemple, le vaccin contre le BCG était utilisé dans des collectivités présentant des taux très élevés de transmission, des degrés équivalents de concentrations entre les individus vaccinés et non vaccinés constitueraient un effet positif du vaccin. Cela semble improbable puisque le taux global de concentration de cas (50\% à $60 \%)$ était similaire à celui observé dans l'ensemble des collectivités autochtones.

Ainsi, si le vaccin ne réduit pas la transmission de la TB telle que l'indique la concentration des cas, le vaccin contre le BCG est-il efficace ? Les gens devraient-ils être vaccinés ? Des données probantes abondantes tirées d'essais clinique (1-3) démontrent que le vaccin contre le BCG réduit la TB active, alors pourquoi n'a-t-il pas fonctionné dans le milieu examiné par Cook et coll. ? Je pense qu'on peut l'expliquer parce que le vaccin contre le BCG a un effet protecteur, mais que sa durée est limitée à une période d'une dizaine d'années (3). La plupart des patients étudiés par Cook et coll. avaient probablement dépassé la période d'immunité. La durée limitée de la protection offerte par le vaccin contre le BCG est tout de même précieuse, car elle est particulièrement efficace pour prévenir la TB disséminée (y compris la méningite [2,3]), qui provoque des maladies dévastatrices chez les enfants. Il est donc toujours raisonnable d'offrir le vaccin contre le BCG aux enfants autochtones, et ce vaccin demeurera justifié jusqu'à ce que le fardeau de la TB au sein de cette collectivité soit réduit au taux observé chez les personnes non autochtones nées au Canada. Comme l'ont souligné Cook et coll., il faudra du temps avant de parvenir à un tel résultat.

Nick R Anthonisen MD Rédacteur en chef, Canadian Respiratory Journal

\section{RÉFÉRENCES}

1. Clemens JD, Chuong JJ, Feinstein AR. The BCG controversy. A methodological and statistical reappraisal. JAMA 1983;249:2362-9.

2. Colditz GA, Brewer TF, Berkey CS et coll. Efficacy of BCG vaccine in the prevention of tuberculosis. Meta-analysis of the published literature. JAMA 1994;271:698-702.

3. Colditz GA, Berkey CS, Mosteller F et coll. The efficacy of bacillus Calmette-Guerin vaccination of newborns and infants in the prevention of tuberculosis: Meta-analyses of the published literature. Pediatrics 1995;96:29-35. 


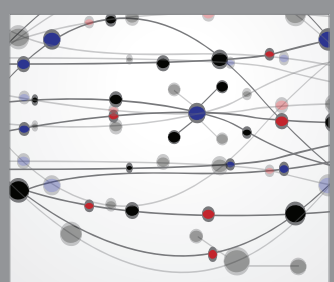

The Scientific World Journal
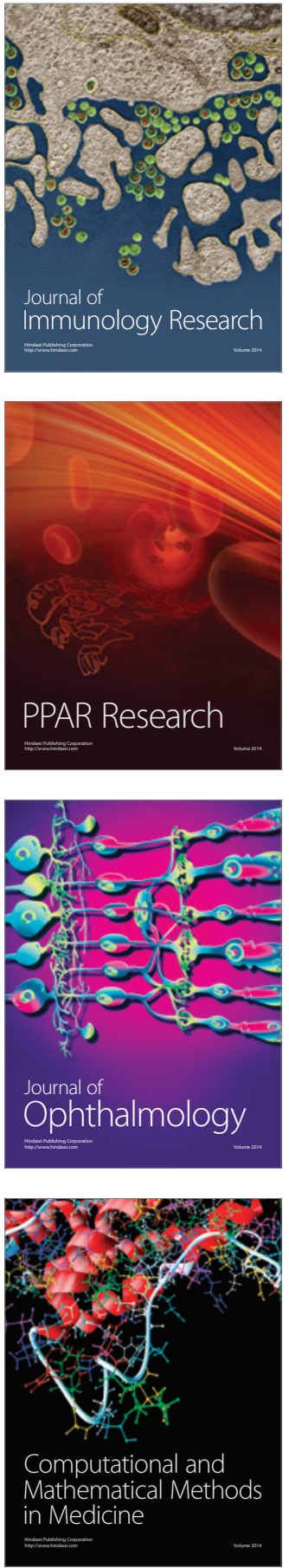

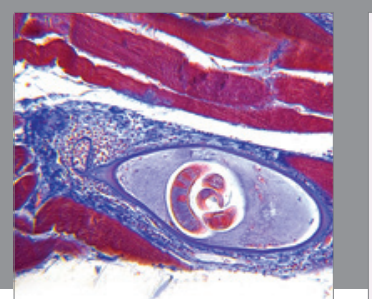

Gastroenterology Research and Practice

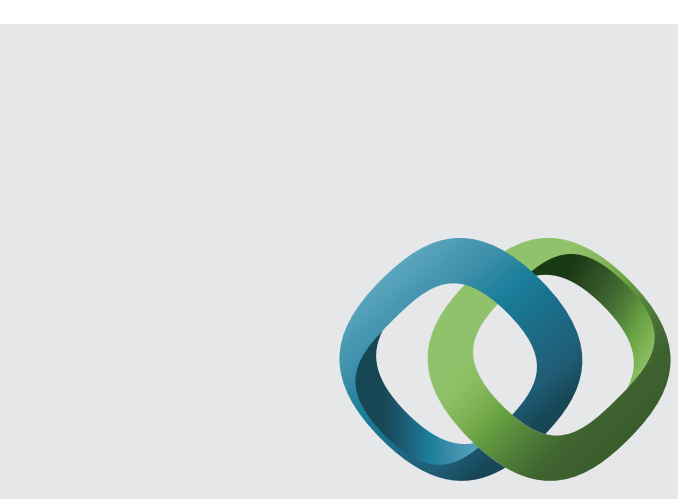

\section{Hindawi}

Submit your manuscripts at

http://www.hindawi.com
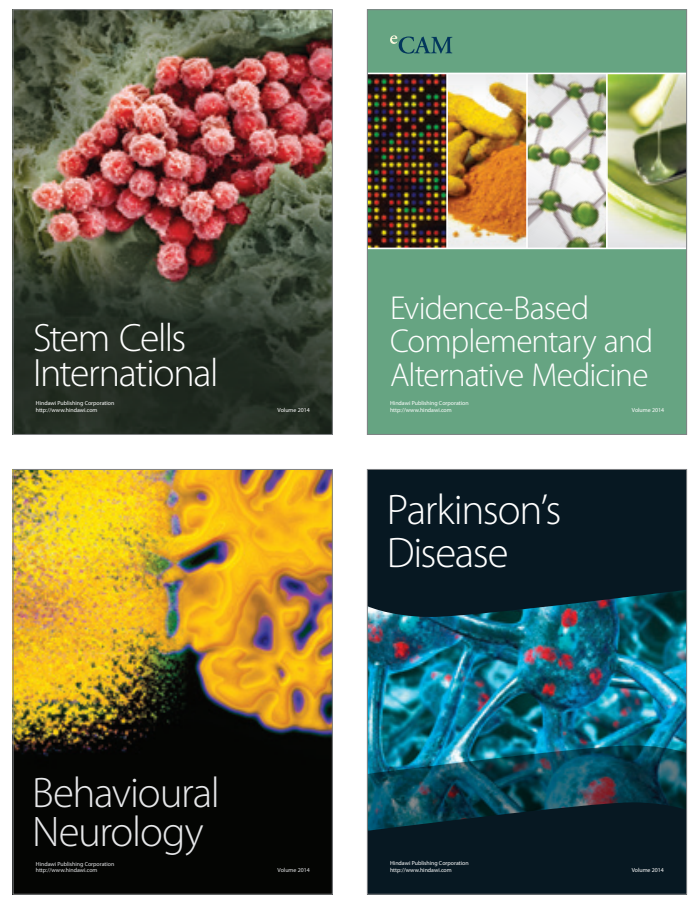
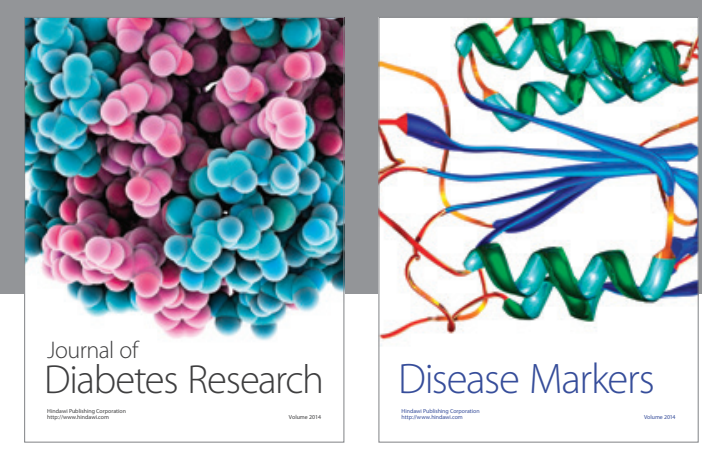

Disease Markers
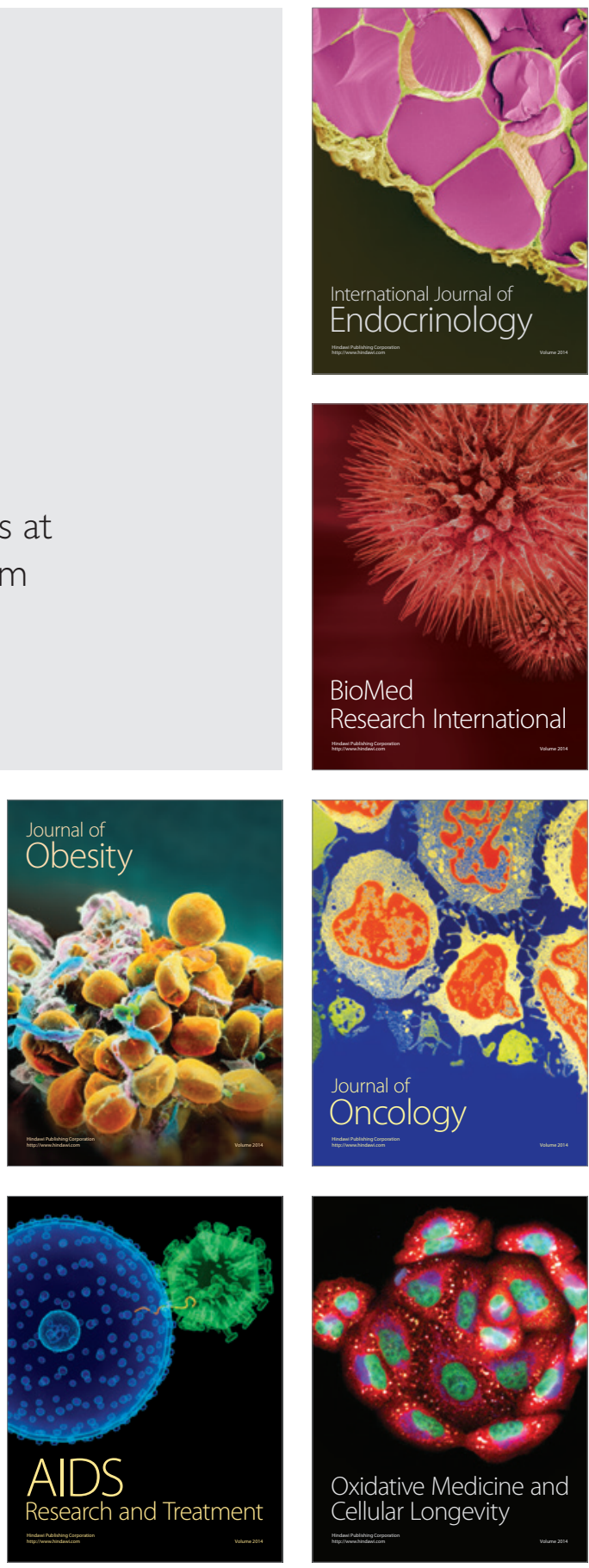